\title{
Between one's own culture and the target culture: the language teacher as intercultural mediator
}

\author{
RichaRd Clouet \\ Universidad de Las Palmas de Gran Canaria
}

Received: 21 April 2005 / Accepted version: 22 May 2005

ISSN: $1697-7467$

\begin{abstract}
The relationship between language and culture is close, and there can be few topics more central to the teaching of English as a foreign language. What is the role of the teacher in providing information and input about a culture? Which culture(s) should be taught? This paper begins by reviewing the literature on the role of culture in EFL teaching, pointing out the particular problems teachers may have to deal with in a context where English has become a lingua franca, so that there is no longer any particular culture associated with the language in general.
\end{abstract}

Key words: culture, mediator, teaching, intercultural, communication.

RESUMEN: Es indudable la asociación entre lengua y cultura y hay pocos temas tan relacionados como este con la enseñanza del inglés como lengua extranjera. Ante las preguntas: ¿cuál es el papel del profesor como transmisor de información y de contenidos culturales? o ¿qué cultura o culturas deben enseñarse? este artículo intenta dar respuesta revisando, en primer lugar, la bibliografía existente acerca del papel de la cultura en la enseñanza del inglés como lengua extranjera. En segundo lugar, se presentan problemas concretos con los que el profesor se enfrenta en un contexto en el que la lengua inglesa ha adquirido el status de lingua franca, lo que se traduce en que ya no quedan aspectos culturales asociados con esta lengua en general.

Palabras clave: cultura, mediador, enseñanza, intercultural, comunicación.

\section{INTRODUCTION}

Culture has become an increasingly important component of English language teaching in the last three decades, but the controversy concerning language acquisition in conjunction with culture is one that is still very present today. Although culture and language are now recognized as an integral part of the language acquisition process -one cannot learn a language without learning its culture- questions as to which culture(s) a teacher should expose learners to have still not been clearly answered. Usually when we hear about culture in the teaching of English as a foreign language, we think about texts describing tea time in Britain or issues related to the American way of life. However, in an increasingly multicultural society where the multicultural use of English is more than obvious, there is an overall feeling that terms need to be redefined. How can culture be defined at the eve of the new millenium and how much culture is needed to teach and learn English? Which culture should we focus on, trying to overcome stereotypes? What is the role of the teacher in providing information and input 
about a culture given the goals of the institutions and students? All these are the questions we shall try to answer in the present article.

\section{Redescovering CULture In THE CONTEXT OF LANGUAGE TEACHING}

Until the mid-twentieth century, people learned a foreign language in order to read and study its literature. In Toward Cultural Proficiency (1985), Allen summarized it:

... prior to the 1960s, the lines between language and culture were carefully drawn.

The primary reason for second language study in the earlier part of this century was access to the great literary masterpieces of civilization (Allen, 1985: 138).

Some years later, Flewelling noted that «it was through reading that students learned of the civilization associated with the target language» (Flewelling, 1993: 339). It is then quite obvious that Nostrand's (1966) paper on «describing and teaching the sociocultural context of a foreign language and literature» presented something of a challenge by suggesting two educational purposes of foreign language teaching: "crosscultural communication and understanding" (Nostrand, 1966: 4).

The sixties were the time when Brooks (1968) «emphasized the importance of culture not for the study of literature but for language learning», as Steele (1989: 155) has observed. Communication started to become the key to language teaching and learning, and the seventies reinforced the emphasis on the context and situation of foreign language teaching and learning with very influential works by authors such as Savignon (1972), Seelye (1974) and Lafayette (1975). That new 'communicative approach' of the seventies eventually replaced the audiolingual method of the sixties. Teacher-oriented texts (Hammerly, 1982; Higgs, 1984; Omaggio, 1986; Rivers, 1981) now also included detailed chapters on culture teaching for the foreign language class, reflecting the prevailing goal: communication within the cultural context of the target language. In Europe, a focus on 'cultural studies' developed in foreign language teaching, as described by Byram (1986, 1988, 1989) and Murphy (1988), and emphasized by Buttjes (1990), Shotton (1991) or Taylor (1991). In short, the importance of culture in foreign language education had considerably increased by the early 1990s.

Culture is now acknowledged as a key element in education, particularly in higher education where "Cultural Studies" form part of most language degrees in Europe. However, whether one is referring to France, Spain or Germany, the content of these subjects may be manifold, from British or American history to Irish folklore, including film studies or ethnography. In short, the perception of the word 'culture' seems to vary considerably from one country to the other.

If we browse the literature in that field, on a general level, culture has been referred to as «the ways of a people» (Lado, 1957), incorporating both 'material' manifestations and 'non-material' ones. Adaskou, Britten \& Fahsi (1990, pp. 3-4) help us define culture on a more specific level by outlining four meanings of culture. Their aesthetic sense includes cinema, literature, music, and media, while their sociological one refers to the organization and nature of family, interpersonal relations, customs, material conditions, and so on. Their semantic sense encompasses the whole conceptualization system which conditions perceptions 
and thought processes, and their pragmatic or sociolinguistic sense refers to the background knowledge, social and paralinguistic skills, and language code which are necessary for successful communication. On the whole, though, it seems to be extremely difficult to find an allinclusive definition of culture, all the more since it is a dynamic concept. It never remains static, but, just as language, is constantly changing (Robinson, 1988).

This is precisely what others refer to as socio-linguistics. Such as Boas (1911), Hymes (1972) and Halliday (1979) were among the first ones to change our view regarding language teaching/learning and the position of language to include the wider context of culture and socio-pragmatics. In particular Halliday's (1979) and Halliday and Hasan's (1984) sociosemiotic view of language emphasized the social meanings of language: "The social structure is not just an ornamental background to linguistic interaction... It is an essential element in the evolution of semantic systems and semantic processes (Halliday, 1979: 114).

Therefore a particular language will reflect the system of values and behaviours inherent to a particular culture, and consequently the very learning of that language will necessarily involve learning the culture the language expresses. Showing language competence then not only involves mastering linguistic skills but also understanding the socio-linguistic aspects of language in order to be able to communicate successfully. Hymes's conception of communicative competence was expanded in the 1990s to include intercultural communicative competence (Byram, 1991 and Kramsch, 1993), in other words the ability to interact in complex cultural contexts among people who embody more than one cultural identity and language, the ability to "reconcile or mediate between different modes present" (Byram and Fleming, 1998: 12). Kramsch also stresses the notion of 'cultural awareness,' central to the whole principle of intercultural communicative competence. Indeed, the learner must be aware not only of the culture of the language being studied, but also of his own culture.

Whether it is called (Fr.) civilisation, (G.) Landeskunde, or (Eng.) culture, culture is often seen as mere information conveyed by the language, not as a feature of language itself; cultural awareness becomes an educational objective in itself, separate from language. If, however, language is seen as social practice, culture becomes the very core of language teaching. Cultural awareness must then be viewed both as enabling language proficiency and as being the outcome of reflection on language proficiency (Kramsch, 1993: 8).

More recently, with the new learner-centered approaches, some scholars like Chowdhury (2003) have tried to reconsider the role of the teacher in the transmission of culture. Chowdhury (2003) argues that both language and the teacher's methods are intertwined with culture. In a teacher-centered environment, the interaction between the cultural values of the teacher and the culture where English is being taught is of very little importance, whereas studentcentered teaching may be culturally biased and make the teaching of culture more flexible to fit with the values of the host culture.

Another influence of the host culture comes from the status of the target language in a definite country. The affective link between the learner and the language being learnt can affect the way the other culture is perceived. Francis and Phyllis (1998) make note of sociocultural issues in relation to language learning and highlight the role of the sociocultural context in the process. The teachers will then be forced to adapt the presentation of culture through language according to the context in which they teach and will particularly have to take into account the attitude towards learning and speaking English.

Nowadays, many researchers like Van Essen (2004) argue for more flexibility in the 
presentation of cultural information. As English has become a lingua franca, the whole approach to the teaching of English language and culture must change. English has effectively become de-nationalized, and there is no longer any particular culture associated with the language in general, so that it becomes hard to choose which culture to teach as background to English. Van Essen emphasizes the importance of learning intercultural communication and to be familiar with problems associated with cross-cultural communication. Instead of explicitly teaching the cultural values of one culture, English effectively becomes a tool with which students may better understand culture in general, fostering cultural understanding and sensitivity. The role that would be played by teaching the language-culture connection is replaced by teaching cross-cultural sensitivity and global awareness in content-based instruction.

Our position in this debate is clear: nobody can deny the importance of English as an international language nowadays. The lingua franca must be seen as a means of communication which should not be bound to culturally specific conditions of use, but should be easily transferable to any cultural setting. Everybody would agree that it is impossible to dissociate culture from EFL, but, at the same time, culture is still viewed as something that students will somehow absorb, while the proper business of a language course is seen as teaching the language; very often, unfortunately, where culture is present, it is restricted to the status of supplementary, background information. Cultural knowledge in foreign language classrooms has remained largely peripheral to language learning, acquired by students incidentally, but rarely focussed on for its own sake.

\section{Culture in the Classroom: a FeW practical techniques}

The next step in this article would be to focus on the kind of culture that should be taught in order to eventually suggest practical techniques for teaching culture in the foreign language classroom. We have pointed out the possible limits to teaching any single culture in the language class. As English has come to be spoken in many parts of the world and has become associated with many different cultures, a problem arises in deciding to which culture students should be effectively expose to. Moreover, native teachers will have to take care in presenting culture in lesson plans, and must be aware that they represent the culture they come from, which affects their own expectations and teaching methods.

Taking into account that the learner's contact with the culture is largely confined to the foreign language classroom, the most plausible approach, in our opinion, would be the inclusion of multiple cultures in the classroom, including the learners' own culture. This exposes learners to different cultures through one single language, English, and can help in the incorporation of cross-cultural understanding. Thus the main issue, as we see it, seems to be one of flexibility.

Tomalin and Stempleski, in the introduction to Cultural Awareness (1993), make the simple and useful distinction between what they call 'big C' (or 'achievement': history, geography, institutions, the arts) Culture and 'little c' (or 'behaviour': traditions and way of life) culture. Very often, however, the coverage of 'little c' culture in coursebooks has rarely got beyond the incidental and the anecdotal. We do believe that if teachers do not transmit all these cultural assumptions and the social contexts in which language operates, they are giving learners nothing but access to an impoverished means of communication. In other 
words, the kind of English they are teaching is effective for survival and for routine transactions, but it lacks much of the cultural resonance required to make it fully meaningful for native speakers.

Cultural learning will only be truly meaningful if it is comparative and contrastive. If we accept the view that teaching culture involves exposing learners to a new set of values, meanings and symbols, then it follows that these new phenomena can only be understood in the light of learners' existing cultural experience. The process of comparison and contrast will lead not only to a better appraisal of the target culture, but also to a greater understanding of the learner's own culture; in this sense all cultural learning can be said to be inter-cultural.

Indeed, English is now used to communicate with native speakers from English speaking countries (the UK, the US, Australia, etc), and non-native speakers from other countries in the world as an international language. At school and in higher education English is generally taught by more non-native teachers than native English speaking teachers. This provides a mixed picture of English use, as it is used both to communicate with native speakers and with non-native speakers, who may not share the cultural assumptions of native speakers. Moreover, it is taught mainly by non-native English speaking teachers who, again, may have different cultural beliefs from the native ones.

This raises the important question of what culture we should be addressing when teaching cultural awareness. If not all communication is taking place with English native speakers, then it may not be relevant to focus exclusively on English speaking culture in all contexts.

Another significant difficulty is avoiding stereotypes when teaching culture. Guest (2002: 160) has argued that attempts to identify national characteristics lead to oversimplification and stereotypes of cultural characteristics. Unfortunately, most materials used till the early nineties (Clarke and Clarke, 1990: 34) illustrated that narrow view of culture, distorting reality, exaggerating some national characteristics and resulting in stereotypes and generalisations. In response to this we believe that it is also the teacher's role to help learners become aware of these stereotypical images, through discussions and critical examinations of them in the classroom.

Cultural comparison is a good way of approaching culture in the language class. As we have seen before, the current view of culture has broadened to an interpretation of culture based on cross-cultural understanding. This obviously involves comparisons and contrasts with the learner's native culture. Dunnet et al. (1986: 148-149) suggest six aspects of culture that learners and teachers should be familiar with:

Languages cannot be translated word-for-word...

The tone of a speaker's voice (the intonation pattern) carries meaning...

Each language-culture employs gestures and body movements which convey meaning...

...languages use different grammatical elements for describing all parts of the

physical world.

All cultures have taboo topics...

In personal relationships, the terms for addressing people vary considerably among languages.

These six features should be taken into account by both teachers and learners of English as a foreign language when analysing their own culture and the culture(s) of the language 
being studied. Then, as learners acquire a new language, they will also be acquiring a new culture; and as their understanding of the foreign language develops, they may come to understand other values and meanings that only belong to the foreign culture, even if their understanding will always be marked by the understanding of their native culture. Hence the learner will always be some kind of go-between between the target culture and his own culture, thus having to interpret constantly instead of acquiring rigid stereotypical notions. Kramsch (1993: 205-206) proposes an examination of four aspects of culture in keeping with this view of cultural acquisition:

1. Establishing a sphere of interculturality (between the target culture and the native culture).

2. Going beyond the presentation of cultural facts and moving towards a process of understanding foreignness.

3. Teaching culture as difference (regarding aspects like age, race, gender, social class, for example).

4. Teachers need to have some understanding of a wider range of subjects such as sociology, ethnography, and sociolinguistics.

In this way learners of English will be able to communicate effectively with English native speakers but also communicate through their own culture and beliefs. Subsequently we entirely agree with Medgyes (1999) when he considers a bilingual teacher to be a more suitable model than a mono-lingual/mono-cultural native speaker. Underlying this approach is the idea of learners and teachers who can mediate between cultures and make communication possible between them.

Concretely, in the classroom, the teaching of culture should take place within the normal language class and not as a separate subject, both through the target language - the language classroom provides plenty of opportunity for 'meta-talk' (Kramsch, 1993: 246) - and the right materials and content. The latter should try to make learners aware of the culture content of language learning and encourage them to compare with their own. Course books such as English File (Oxendon and Latham-Koneig, 2000) and Interchange (Richards, 2000) provide good examples of materials that encourage learners to compare cultures and to take a critical perspective. Materials should also promote discussions, comparisons and reflection on both own and target cultures, including such subjects as cultural symbols and products e.g. popular images, architecture, landscapes, cultural behaviour e.g. what is considered appropriate, values and attitudes, patterns of communication e.g. non-verbal communication, and exploring cultural experiences e.g. looking at learners own feelings and experiences of the target culture (Tomalin and Stempleski, 1993: 11-12). Certainly many primary texts (novels, films, articles etc) may be too difficult for some learners to deal with, but teachers may make use of a wide range of authentic materials, including advertisements, contemporary songs and literary texts and get accustomed to operating multi-media classrooms. They will have to change their pedagogical habits: up to now all the authentic materials and the technological resources have been used exclusively in the service of language learning; now such materials should be examined from the point of view of content - whether it is a news story, a poem, a vox pop interview or an extract from a soap opera - and not purely as a vehicle for language development. After all, they are language teachers and their attitude as language teachers is too often to teach a lot 
of language - particularly a lot of grammar. Their new challenge must be to make crosscultural awareness a central issue in teaching at the same time as developing students' linguistic competence.

Many times, when an attempt to teach culture is made in the language class, it is often done essentially through 'discussion' activities. Such activities are definitely a valuable form of learning culture, but not the only one. Furthermore, not all students can be expected to be able to discuss some complex issues at a high level in a foreign language. Experience has demonstrated that quizzes are a successful type of activity to teach new information - and not only to check previously taught materials, which is often the case. A true and false quiz answered in pairs will, for instance, allow students to share knowledge and make predictions. By predicting, the students will actually become more interested in finding out the right answers. This will force them to review their existing knowledge of the topic and raise their curiosity about whether their prediction is correct or not. The answers will not necessarily be given by the teacher; they can also be given through a reading or listening activity, or by watching a video. This is precisely when extra information can be provided by the teacher. Thus, quizzes represent a high-interest activity that keeps students involved and teaches them in an entertaining way.

The activities should also encourage contrast and comparison. For example, as students watch a video or are engaged with some other materials, they could be asked to point out some particular features that strike them. In that way, students watching a video about food habits in Britain might note all the differences with their own culture and thus might be surprised by the time British people have lunch or dinner. This kind of activity turns the use of any materials into an active task, rather than simply passive viewing or listening.

Some other types of activity that can be found useful include research, games, role plays or field trips. Generally speaking, most standard language activities can be easily adapted for use in the culture classroom. The most important point is to ensure that the students are actively engaged in the target culture and language, and are deliberately introduced to contrasts with their own culture.

Finally, teachers must bear in mind that the field of culture is enormous and that everything cannot be covered. They will only provide some pathways to help their students come to terms with some elements of the foreign culture, and to teach them to see their own culture from the outside. Indeed, intercultural understanding runs both ways.

\section{Conclusion}

The answer to the questions we asked at the beginning of this paper would definitely be that culture and language are an integral part of the language acquisition process. One cannot learn a language without learning its culture. But at the same time, cultural learning will only be truly meaningful if it is comparative and contrastive. Cross-cultural comparison will expose learners to a new set of values, meanings and symbols that can be understood in the light of their own cultural experience. When learning a foreign language, not only are we gaining access to a different way of viewing and understanding the world, but also of reconsidering our own world-view. When carried out in this way, cultural learning can be said to be intercultural. 


\section{REFERENCES}

Adaskou, K., Britten, D. y Fahsi, B. (1990). "Design decisions on the cultural content of a secondary English course for Morocco", en ELT Journal, 44, 1: 3-10.

Allen, W. (1985). "Toward cultural proficiency", en A.C. Omaggio (ed.), Proficiency, curriculum, articulation: The ties that bind. Middlebury, VT: Northeast Conference, 137-166.

Barro, A., Jordan, S. y Roberts, C. (2001). "La práctica cultural en la vida cotidiana: el estudiante de idiomas como etnógrafo", en M. Byram y M. Fleming, Perspectivas interculturales en el aprendizaje de idiomas. Madrid: Cambridge University Press, 82-103.

Boas, F. (1911). "Language and thought", en Valdes, J. (1986), Culture Bound. Cambridge: Cambridge University Press.

Brooks, N. (1968). Teaching culture in the foreign language classroom. Foreign Language Annals, 1, 204-217.

Brown, G. (1990). "Cultural values: The interpretation of discourse", en ELT Journal, 44, 1: 1117.

Buttjes, D. (1990). "Teaching foreign language and culture: Social impact and political significance", en Language Learning Journal, 2: 53-57.

Buttjes, D. y Byram, M. (eds.) (1991). Mediating languages and cultures. Clevedon: Avon.

Byram, M. (1986). "Cultural studies in foreign language teaching", en Language Teaching, 19: 322-336.

Byram, M. (1988). "Foreign language education and cultural studies", en Language, Culture and Curriculum, 1(1): 15-31.

Byram, M. (1989). Cultural studies in foreign language education. Clevedon, Avon: Multilingual Matters.

Byram, M. (1991). "Teaching Culture and Language: Towards an Integrated Model”, en Buttjes, D. \& Byram, M. (eds.) Mediating languages and cultures. Clevedon, Avon, England: Multilingual Matters.

Byram, M. (ed.) (1994). Culture and language learning in higher education. Clevedon, Avon: Multilingual Matters.

Byram, M. y Esarte-Sarries, V. (1991). Investigating cultural studies in foreign language teaching. Clevedon, Avon: Multilingual Matters.

Byram, M., Esarte-Sarries, V. y Taylor, L. (1991). Cultural studies and language learning: A research report. Clevedon, Avon: Multilingual Matters.

Byram, M., Morgan, C. y Colleagues. (1994). Teaching-and-learning language-and-culture. Clevedon, Avon: Multilingual Matters.

Byram, M. y Fleming, M. (1998). Language Learning in Intercultural Perspective. Cambridge: Cambridge University Press.

Chowdhury, R. (2003). "International TESOL training and EFL contexts: The cultural disillusionment factor", en Australian Journal of Education, 47.

Clarke J. and M. (1990). "Stereotyping in TESOL Materials", en Harrison B. (ed.), Culture and the Language Classroom. Hong Kong: Modern English Publications and the British Council.

Díaz-Aguado, M. J. (2003). Educación intercultural y aprendizaje cooperativo. Madrid: Ediciones Pirámide.

Dunnett, S., Dubin, F. y Lezberg, A. (1986). "English Language Teaching from an Intercultural Perspective", en J. Valdes, J. (ed.), Culture Bound. Cambridge: Cambridge University Press. 
Flewelling, J. (1993). "Teaching culture in the '90s: Implementing the National Core French Study syllabus", en Canadian Modern Language Review, 49, 1: 338-344.

Flewelling, J. (1994). "The teaching of culture: Guidelines from the National Core French Study of Canada", en Foreign Language Annals, 27, 1: 133-142.

Francis, N. y Phyllis R. M. (1998). "English as an international language of prestige: Conflicting cultural perspectives and shifting ethnolinguistic loyalties", en Anthropology \& Education Quarterly, 29.

Guest, M. (2002). “A critical 'checkbook' for culture teaching and learning”, en ELT Journal, 56, 2: $154-161$

Halliday, M. (1979). Language as social semiotic. Victoria: Edward Arnold.

Halliday, M and Hasan, R. (1984). Language, context, and text: Aspects of language in a socialsemiotic perspective. Victoria: Deakin University Press.

Hammerly, H. (1982). Synthesis in language teaching. Blaine, WA: Second Language Publications.

Higgs, T. (ed.) (1984). Teaching for proficiency, The organizing principle. Lincolnwood, IL: National Textbook Company.

Higgs, T. (1990). "Language as culture: Teaching culture from a functional perspective", en I. Maihot-Bernard y D.M. Crashman (eds.), Canada's languages: A time to reevaluate. Proceedings of the Official Languages Education Conference, 1988, 74-84.

Hymes, D. (1972). "On communicative competence”, en J. Pride y J. Holmes (eds.), Sociolinguistics. Harmondsworth: Penguin: 269-293

Kramsch, C. (1993). Context and Culture in Language Teaching. Oxford: Oxford University Press.

Kramsch, C. y Sullivan, P. (1996). "Appropriate pedagogy", en ELT Journal 50, 3: 199-212

Kramsch, C. (1988). "The cultural discourse of foreign language textbooks", en A. Singerman (ed.), Towards a new integration of language and culture. Middlebury, VT: Northeast Conference, 63-68.

Kramsch, C., Cain, A. y Murphy-Lejeune, E. (1996). "Why should language teachers teach culture?", en Language, Culture and Curriculum, 9, 1: 99-107.

Lado, R. (1957). Linguistics across cultures: Applied linguistics for language teachers. Ann Ardor: University of Michigan Press.

Lado, R. (1986). "How to compare two cultures", en J. Valdes (ed.), Culture Bound. Cambridge: Cambridge University Press.

Lafayette, R.C. (1978). Teaching Culture: Strategies and Techniques. Virginia: Arlington.

Lafayette, R. (1975). The cultural revolution in foreign languages: A guide for building the modern curriculum. Lincolnwood, IL: National Textbook Company.

Medgyes, P. (1999). The non-native teacher (2nd ed.) Ismaning: Hueber

Murphy, E. (1988). "The cultural dimension in foreign language teaching: Four models. Language", en Culture and Curriculum, 1, 2: 147-163.

Nostrand, H. (1966). "Describing and teaching the sociocultural context of a foreign language and literature", en A. Valdman (ed.), Trends in language teaching. New York: McGraw-Hill, 125.

Omaggio, A. (1986). Teaching language in context: Proficiency-oriented instruction. Boston: Heinle \& Heinle.

Oxenden, C. y Latham-Koenig, C. (1999). English File. Oxford: Oxford University Press.

Richards, J. (2000). New Interchange. Cambridge: Cambridge University Press.

Rivers, W. (1981). Teaching foreign language skills (2nd ed.). Chicago: University of Chicago Press.

Robinson, G. (1981). Issues in second language and cross- cultural education: The forest through the trees. Boston: Heinle \& Heinle. 
Robinson, G. (1988). Crosscultural understanding. New York: Prentice-Hall.

Savignon, S. (1972). Communicative competence: An experiment in foreign language testing. Philadelphia: Centre for Curriculum Development.

Seelye, H. (1974). Teaching culture: Strategies for inter-cultural communication. Skokie, IL: National Textbook Company.

Shotton, R. (1991). "Cultural studies in foreign language education”, en Language Learning Journal, 3: $68-70$.

Steele, R. (1989). "Teaching language and culture: Old problems and new approaches", en J.E. Alatis (ed.), Georgetown University roundtable on languages and linguistics. Washington: Georgetown University Press, 153-162.

Tomalin, B. y Stempleski, S. (1993). Cultural Awareness. Oxford: Oxford University Press.

Trujillo Sáez, F. (2001). "Objetivos en la enseñanza de lenguas extranjeras: De la competencia lingüística a la competencia intercultural", en F. Herrera Clavero, F. Mateos Claros, S. Ramírez Fernández, M.I. Ramírez Salguero y J.M. Roa Venegas (coords.), Inmigración, interculturalidad y convivencia. Ceuta: Instituto de Estudios Ceutíes, 407-418.

Trujillo Sáez, F. (2002). "Towards interculturality through language teaching: argumentative discourse", en Cauce. Revista de Filología y su Didáctica, 25, 103-120.

Van Essen, A. (2004). "The rise and role of English as an international language. Some educational consequences", en Humanising Language Teaching, 6, 4: 1-9. 